\title{
Effect of Biochar Type and Size on in Vitro Rumen Fermentation of Orchard Grass Hay
}

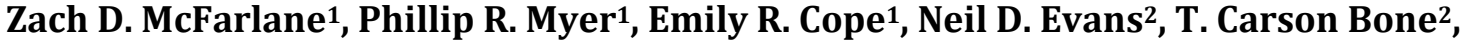 \\ Bryan E. Biss ${ }^{2}$, J. Travis Mulliniks ${ }^{*}$
}

${ }^{1}$ Department of Animal Science, University of Tennessee, Knoxville, TN, USA

${ }^{2}$ Proton Power, Lenoir City, TN, USA

Email:*jmulli@utk.edu

How to cite this paper: McFarlane, Z.D., Myer, P.R., Cope, E.R., Evans, N.D., Bone, T.C., Biss, B.E. and Mulliniks, J.T. (2017) Effect of Biochar Type and Size on in Vitro Rumen Fermentation of Orchard Grass Hay. Agricultural Sciences, 8, 316-325. https://doi.org/10.4236/as.2017.84023

Received: March 22, 2017

Accepted: April 27, 2017

Published: April 30, 2017

Copyright $\odot 2017$ by authors and Scientific Research Publishing Inc. This work is licensed under the Creative Commons Attribution International License (CC BY 4.0).

http://creativecommons.org/licenses/by/4.0/

\begin{abstract}
Biochar, a byproduct from the biofuels industry, may be a potential feed additive in ruminant diets due to possible improvements in microbial fermentation. Therefore, the objective of this study was to determine the nutritive value, in vitro digestibility, volatile fatty acid (VFA) production, and gas production of biochar inclusion to an orchard grass (Dactylis glomerata) basal diet. The study was designed as a $3 \times 2$ factorial arrangement with 3 different biochar sources and 2 biochar processed sizes as the main effects factors. Experimental treatments were biochar from 3 different tree types: 1) Chestnut Oak (Quercus prinus L.; CO), 2) Yellow Poplar (Liriodendron tulipifera; YP), or 3) White Pine (Pinus strobus L.; WP), and processed at 2 different biochar particle sizes: a) $<178 \mu \mathrm{m}$ (Fine) or b) $>178 \mu \mathrm{m}$ (Coarse). Biochar was added to the basal diet of orchard grass hay $(872.35 \mathrm{~g} / \mathrm{kg}$ of DM, $98.31 \mathrm{~g} / \mathrm{kg}$ of CP, and $704.02 \mathrm{~g} / \mathrm{kg}$ of aNDF, DM basis) at a rate of $81 \mathrm{~g} / \mathrm{kg}$ DM. Biochar residual ash content was greater $(P<0.01)$ for Fine particle size and greater $(P<0.01)$ for $\mathrm{CO}$ and YP biochar sources. Biochar aNDF content exhibited a type $\times$ size interaction $(P=0.01)$ with lower aNDF content in both WP sizes compared with their respective biochar type and size. Gas production was not influenced $(P=0.23)$ by biochar tree type; however, gas production was increased $(P=$ $0.05)$ by Fine particle size compared with Coarse biochar. The in vitro true digestibility (IVTD) of orchard grass hay was increased $(P=0.01)$ by the inclusion of Fine biochar particle size compared with Coarse particle size. Additionally, in vitro $\mathrm{CP}$ true digestibility (DCP) exhibited a type $\times$ size interaction $(P=0.01)$. Crude protein digestibility was lower for Fine particle-sized CO and WP biochar sources compared with Coarse particle-sized CO and WP (P $\leq$ 0.004). However, DCP was not different between Coarse and Fine particlesized YP biochar $(P=0.70)$. Volatile fatty acids (acetate, propionate, and butyrate) were not altered by biochar type $(P \geq 0.66)$ or particle size $(P \geq 0.19)$. These results indicate that both tree type and particle size of biochar may need
\end{abstract}


to be carefully considered before incorporating into a ruminant diet. Furthermore, Fine particle-sized biochar may be the most effective to incorporate as a feed additive in a ruminant diet based on digestibility parameters.

\section{Keywords}

Biochar, Forage Digestibility, Gas Production, Rumen Fermentation

\section{Introduction}

Biochar is a byproduct attained when biomass is subjected to pyrolysis, typically in the biofuel industry. This process subjects biomass, such as trees, forages, straws, and agricultural waste, to heat at moderately low temperatures with a limited amount of oxygen [1]. Biochar and charcoal are produced similarly, which activated charcoal has been used as a feed additive in ruminant diets [2] [3]. In addition, charcoal has been used as an additive to improve growth performance, feed efficiency, and as a detoxifying agent in ruminants [4]. Comparatively to charcoal, the increased surface area and porous structure of biochar may aid in gas sorption, providing the potential as a feed additive [1]. Research focusing on methane mitigation have shown promise with biochar during in vitro [5] [6] [7] and in vivo [8] studies. However, more extensive research is necessary to determine the potential benefits and impacts of biochar on forage digestibility and rumen fermentation kinetics. Thus, our hypothesis was that biochar type would not impact rumen fermentation, but a larger particle size would inhibit rumen fermentation. Therefore, the objective of this study was to determine the effect of biochar source and particle size on nutritive value, in vitro forage digestibility, volatile fatty acid (VFA) production, and gas production.

\section{Materials and Methods}

\subsection{Study Design}

Treatments were arranged as a $3 \times 2$ factorial with 3 commercial biochar tree types: 1) yellow poplar (Liriodendron tulipifera; YP), 2) white pine (Pinus strobus L.; WP), or 3) chestnut oak (Quercus prinus L.; CO) and 2 different biochar particle sizes: a) $<178 \mu \mathrm{m}$ (Fine) or b) $>178 \mu \mathrm{m}$ (Coarse). The basal diet (872.35 $\mathrm{g} / \mathrm{kg}$ of DM, $98.31 \mathrm{~g} / \mathrm{kg}$ of CP, and $704.02 \mathrm{~g} / \mathrm{kg}$ of aNDF, DM basis) consisted of orchard grass (Dactylis glomerata) hay. Biochar was added to the basal diet at a rate of $81 \mathrm{~g} / \mathrm{kg}$ of DM.

\subsection{Biochar Production}

Biochar was provided by Proton Power, Inc., Lenoir City, TN. Proton Power utilized tree types that are highly present in Eastern Tennessee. For each tree type, wood chips were generated separately from whole logs using a brush chipper (Vermeer BC1000XL, Pella, IA). Wet wood crumbles were generated by using a Forest Concepts $6.4 \mathrm{~mm}$ M24ci Crumbler (Forest Concepts, LLC, Auburn, WA) 
and then were pyrolized using a Proton Power $\mathrm{CHyP}$ engine (Proton Power, Inc., Lenoir City, $\mathrm{TN}$ ) at a peak temperature of $1110^{\circ} \mathrm{C}$ with a residence time greater than $3 \mathrm{~min}$. Biochar was collected in a sealed metal bin and allowed to cool. Biochar samples were fractionated utilizing a single deck orbital separator (SWECO LS24S44, SWECO, Florence, KY) equipped with a Market Grade 80 mesh screen (178 $\mu \mathrm{m}$ opening) woven with a $0.14 \mathrm{~mm}$ diameter stainless steel wire. For each tree species, one sample (Fine) was collected from the sieved biochar particles below the 80 mesh screen (178 $\mu \mathrm{m}$ opening) and one sample (Coarse) was collected from the biochar particles remaining on top of the screen.

\subsection{Scanning Electron Microscopy}

The different biochar types were characterized by scanning electron microscopy (SEM) in a FEI Quanta 200 at $15 \mathrm{kV}$. Secondary electron (SE) imaging revealed topographical information, and back-scattered electron (BSE) imaging modes emphasized features due to atomic number contrast. Biochars examined were affixed to conventional specimen stubs via the use of double-sided adhesive tape; the adhesive surface was merely pressed into the sample of char, placed into the SEM, and imaged.

\subsection{Forage Proximate Analysis}

Orchardgrass hay and biochar samples were analyzed for dry matter (DM), ash, crude protein (CP), and neutral detergent fiber (aNDF) content. The DM content of the samples was determined by drying at $55^{\circ} \mathrm{C}$ in a forced-air oven for 48 h. Samples were then lyophilized and ground through a 2-mm screen using a Wiley mill (Thomas Scientific, Swedesboro, NJ). Crude protein was determined by total $\mathrm{N}$ combustion analysis (Leco Instruments, Inc., St. Joseph, MI) [9]. Ash was determined after complete combustion in a muffled furnace (L\&L Special Furnace Co., Inc., XLB Series, Aston, PA) at $550^{\circ} \mathrm{C}$ for $6 \mathrm{~h}$ [9]. Neutral detergent fiber (aNDF) content was assessed utilizing the ANKOM 200 fiber analysis system (ANKOM Corp., Fairport, NY).

\subsection{Gas Production Sample Preparation}

To determine $48 \mathrm{~h}$ gas production, rumen extrusa was immediately added to Ankom $^{\mathrm{RF}}$ Gas Production system modules (ANKOM Corp., Fairport, NY) along with the basal diet $(0.50 \pm 0.01 \mathrm{~g})$ and biochar at a level of $81 \mathrm{~g} / \mathrm{kg} \mathrm{DM}$ as previously reported by [10]. Rumen fluid was collected into a preheated thermal flask $\left(39^{\circ} \mathrm{C} \pm 0.5^{\circ} \mathrm{C}\right)$ and filtered through 3 layers of cheesecloth to eliminate feed particles. Rumen fluid $(35 \mathrm{~mL})$ was buffered utilizing McDougall's artificial saliva [11] in a 1:4 dilution of rumen fluid to buffer. Each bottle $(620 \mathrm{~mL})$ was filled with rumen extrusa and sample leaving a corresponding headspace volume of $585 \mathrm{~mL}$. The bottles were placed into a water bath (Orbital Water Bath Shaker, Model 3540, Lab Line, Melrose Park, IL) at $39^{\circ} \mathrm{C} \pm 0.5^{\circ} \mathrm{C}$ for $48 \mathrm{~h}$ while being agitated (50 RPM). Data was automatically generated by the Ankom pressure sensor module (pressure accuracy: $0 \pm 0.2 \mathrm{psi}$ accuracy) to a local computer at 
intervals of $5 \mathrm{~min}$. Gas production data were analyzed to compare the changes in pressure in the head space at $0,3,6,12,24$, and $48 \mathrm{~h}$ of incubation in triplicates.

\subsection{VFA Analysis}

An analytical subsample of rumen fluid was collected from each Ankom ${ }^{\mathrm{RF}}$ Gas Production system module (ANKOM Corp., Fairport, NY) at the end of each 48 $\mathrm{h}$ incubation experiment for VFA analysis. Rumen samples were prepared by centrifuging strained samples at $10,000 \times \mathrm{g}$ for $10 \mathrm{~min}$ at $4^{\circ} \mathrm{C}$. A mixture of $5 \mathrm{~mL}$ of ruminal fluid supernatant and $1 \mathrm{~mL}$ of meta-phosphoric acid-2ethyl butyric acid solution was then prepared. This mixture was allowed to stand in an ice bath for $\geq 30 \mathrm{~min}$ and then prepared for a second centrifuge for $10 \mathrm{~min}$ at $10,000 \times \mathrm{g}$ and $4^{\circ} \mathrm{C}$. The samples were then analyzed using a gas chromatograph (Agilent 7890B, Agilent Technologies, Inc., Santa Clara, CA) with the previously described method [12]. The gas chromatograph was equipped with a FID detector, Nukol Fused Silica capillary column (Supelco, Sigma-Aldrich Co., LLC, Bellefonte, PA), and Helium as the carrier gas.

\subsection{Forage Digestibility}

The Daisy II in vitro fermentation system (ANKOM Corp., Fairport, NY) was utilized to examine the rate and extent of DM and fiber degradation of forages with the addition of biochar. Each substrate $(500 \pm 20 \mathrm{mg})$ was weighed into artificial fiber bags (\#F57, ANKOM Corp.), which were then heat-sealed. Groups of 24 bags, including two empty bags for correction, were placed upright in plastic containers. Rumen fluid was buffered utilizing a 1:4 dilution of rumen fluid to buffer. Ruminal fluid $(400 \mathrm{~mL})$ was added to each ANKOM fermentation jar with an additional $1600 \mathrm{~mL}$ of buffer [13] that was adjusted to $\mathrm{pH}$ 6.8. Bags, in addition to all liquid contents in the plastic containers, were then added to the fermentation jars. Fermentation was initiated for $48 \mathrm{~h}$ at $39^{\circ} \mathrm{C}$. Bags were removed and washed under cold tap water until excess water ran clear. Fiber (aNDF) degradation was determined sequentially on the same bags with $\alpha$ amylase and sodium sulfite (Mertens, 2002) using the ANKOM200 fiber analysis system (ANKOM Corp., Fairport, NY). Crude protein was determined by total $\mathrm{N}$ combustion analysis (Leco Instruments, Inc., St. Joseph, MI).

\subsection{Statistical Analysis}

Samples were analyzed as a completely randomized design using the MIXED procedure (SAS Inst. Inc., Cary, NC, USA) to test differences among the 7 treatment combinations, and contrasts (without control) tested main effects of biochar type and size and their interaction. Repeated measures were utilized for variables collected over time. Least squares means were compared using Fisher's LSD at a significance level of $P \leq 0.05$.

\section{Results}

Dry matter was not different among biochar tree types $(P=0.22$; Table 1$)$ or 
Table 1. Chemical composition of different biochar tree types (CO, Chestnut Oak; YP, Yellow Poplar; WP, White Pine) and particle sizes.

\begin{tabular}{|c|c|c|c|c|c|c|c|c|c|c|}
\hline \multirow[b]{3}{*}{ Measurements } & \multicolumn{7}{|c|}{ Treatment } & & & \\
\hline & \multicolumn{2}{|c|}{$\mathrm{CO}$} & \multicolumn{2}{|c|}{ YP } & \multicolumn{2}{|c|}{ WP } & \multirow[b]{2}{*}{ SEM } & \multicolumn{3}{|c|}{$P$-value } \\
\hline & Fine & Coarse & Fine & Coarse & Fine & Coarse & & Type & Size & Source $\times$ Size \\
\hline $\mathrm{DM}(\mathrm{g} / \mathrm{kg})$ & $976.82^{\mathrm{a}}$ & $954.37^{\mathrm{a}}$ & $960.23^{\mathrm{a}}$ & $982.32^{\mathrm{a}}$ & $856.48^{\mathrm{a}}$ & $952.12^{\mathrm{a}}$ & 372.18 & 0.22 & 0.34 & 0.34 \\
\hline Ash (g/kg) & $187.86^{\mathrm{a}}$ & $72.41^{\mathrm{bc}}$ & $199.37^{\mathrm{a}}$ & $71.74^{\mathrm{bc}}$ & $95.35^{\mathrm{b}}$ & $44.62^{\mathrm{c}}$ & 14.44 & 0.007 & 0.001 & 0.08 \\
\hline aNDF (g/kg) & $800.71^{\mathrm{c}}$ & $1002.48^{\mathrm{a}}$ & $843.79^{c}$ & $1027.09^{\mathrm{a}}$ & $666.31^{\mathrm{d}}$ & $954.07^{\mathrm{b}}$ & 12.45 & 0.001 & $<0.001$ & 0.01 \\
\hline
\end{tabular}

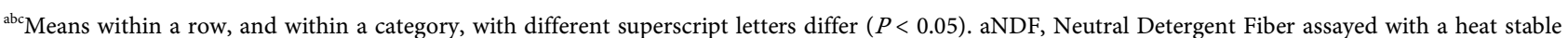
amylase and expressed inclusive of residual ash; CO, Chestnut Oak; Coarse, 300 - $1000 \mu \mathrm{m}$; CP, crude protein; DM, dry matter; Fine, 140 - $178 \mu$ m; SEM, standard error of the mean; YP, Yellow Poplar; WP, White Pine.

between particle sizes $(P=0.34)$. In addition, $\mathrm{CP}$ was not different for tree type $(P=0.12)$ or particle size $(P=0.21)$ of biochar. Residual ash content of the CO and YP samples was greater $(P=0.007)$ compared to WP biochar. Fine particlesized biochar had greater $(P=0.001)$ residual ash compared with the larger particle size. In addition, aNDF content exhibited a type $\times$ size $(P=0.01)$ interaction. Neutral detergent fiber was greater for coarse particle-sized biochar for all biochar tree types. Within particle size, there were no differences in aNDF content between CO and YP biochar sources. However, aNDF content was lower for WP biochar than CO and YP biochar sources within their respective particle sizes.

Gas production was not influenced ( $P=0.23$; Table 2$)$ by tree type. However, gas production was greater $(P=0.05)$ for fine particle-sized biochar compared to its larger counterpart.

Forage digestibility was not different $(P=0.35$; Table 2$)$ by biochar tree type. However, forage digestibility (IVTD) was greater $(P=0.01)$ with fine particle size compared to coarse. In vitro $\mathrm{CP}$ digestibility (DCP) exhibited a type $\times$ size interaction $(P=0.01)$. Crude protein digestibility was decreased for fine particle-sized $\mathrm{CO}$ and WP biochar sources compared to their larger counterparts. However, DCP was not different between coarse and fine particle-sized YP biochar.

Acetate production was not impacted by tree type $(P=0.95$; Table 3$)$ or particle size $(P=0.33)$. In addition, the production of propionate was not influenced by type $(P=0.66)$ or particle size $(P=0.19)$. Finally, butyrate production did not differ by tree type $(P=0.97)$ or particle size $(P=0.23)$. Acetate: propionate ratio was also not different for biochar type $(P=0.31)$ or particle size $(P=$ 0.99).

\section{Discussion}

Tree type and particle size of biochar samples utilized in this study differed in ash and aNDF content, but did not differ in CP content. The differences in ash and aNDF content may have decreased digestibility of the orchard grass hay 
Table 2. Effects of biochar addition on in vitro forage degradability and gas production.

\begin{tabular}{ccccccccccc}
\hline & \multicolumn{9}{c}{ Treatment } \\
\hline & \multicolumn{2}{c}{ CO } & \multicolumn{2}{c}{ YP } & \multicolumn{2}{c}{ WP } & & & \multicolumn{2}{c}{$P$-value } \\
\hline Measurement $^{1}$ & Fine & Coarse & Fine & Coarse & Fine & Coarse & SEM & Type & Size & Source $\times$ Size \\
\hline GP $(\mathrm{mL} / \mathrm{g} \mathrm{DM})$ & $-0.2^{\mathrm{c}}$ & $1.8^{\mathrm{abc}}$ & $6.2^{\mathrm{ab}}$ & $1.2^{\mathrm{c}}$ & $6.9^{\mathrm{a}}$ & $1.1^{\mathrm{bc}}$ & 1.45 & 0.23 & 0.05 & 0.06 \\
IVTD $(\mathrm{g} / \mathrm{kg} \mathrm{DM})$ & $-41.4^{\mathrm{ab}}$ & $-41.6^{\mathrm{ab}}$ & $-35.4^{\mathrm{ab}}$ & $-85.5^{\mathrm{c}}$ & $-18.6^{\mathrm{a}}$ & $-72.3^{\mathrm{bc}}$ & 12.8 & 0.35 & 0.01 & 0.13 \\
DCP $(\mathrm{g} / \mathrm{kg} \mathrm{DM})$ & $-47.7^{\mathrm{b}}$ & $14.5^{\mathrm{a}}$ & $-6.9^{\mathrm{a}}$ & $-12.7^{\mathrm{a}}$ & $-84.2^{\mathrm{c}}$ & $-10.1^{\mathrm{a}}$ & 10.3 & 0.02 & 0.001 & 0.01 \\
\hline
\end{tabular}

${ }^{1}$ These values are representative of the change in response compared to the orchard grass hay control. ${ }^{\text {abc }}$ Means within a row, and within a category, with different superscript letters differ $(P<0.05)$. aNDF, Neutral Detergent Fiber assayed with a heat stable amylase and expressed inclusive of residual ash ; CO, Chestnut Oak; Coarse, $300-1000 \mu \mathrm{m}$; CP, crude protein; DM, dry matter; Fine, 140 - 178 m; SEM, standard error of the mean; YP, Yellow Poplar; WP, White Pine.

Table 3. Effects of biochar addition on in vitro volatile fatty acid production.

\begin{tabular}{|c|c|c|c|c|c|c|c|c|c|c|}
\hline \multirow[b]{3}{*}{ Total VFA $(\mathrm{mM})^{1}$} & \multicolumn{7}{|c|}{ Treatment } & \multirow{2}{*}{\multicolumn{3}{|c|}{$P$-value }} \\
\hline & \multicolumn{2}{|c|}{$\mathrm{CO}$} & \multicolumn{2}{|c|}{ YP } & \multicolumn{2}{|c|}{ WP } & \multirow[b]{2}{*}{ SEM } & & & \\
\hline & Fine & Coarse & Fine & Coarse & Fine & Coarse & & Type & Size & Type $\times$ Size \\
\hline Acetate & $6.28^{\mathrm{a}}$ & $-8.02^{\mathrm{a}}$ & $4.25^{\mathrm{a}}$ & $-1.85^{\mathrm{a}}$ & $6.17^{\mathrm{a}}$ & $-0.85^{\mathrm{a}}$ & 10.98 & 0.95 & 0.33 & 0.92 \\
\hline Propionate & $1.37^{\mathrm{a}}$ & $-2.25^{\mathrm{a}}$ & $1.71^{\mathrm{a}}$ & $0.48^{\mathrm{a}}$ & $0.98^{\mathrm{a}}$ & $0.20^{\mathrm{a}}$ & 1.69 & 0.66 & 0.19 & 0.67 \\
\hline Butyrate & $0.37^{\mathrm{a}}$ & $-0.57^{\mathrm{a}}$ & $0.43^{\mathrm{a}}$ & $-0.49^{\mathrm{a}}$ & $0.25^{\mathrm{a}}$ & $-0.07^{\mathrm{a}}$ & 0.71 & 0.97 & 0.23 & 0.88 \\
\hline Acetate: Propionate & $-0.01^{\mathrm{a}}$ & $0.41^{\mathrm{a}}$ & $-0.51^{\mathrm{a}}$ & $-0.42^{\mathrm{a}}$ & $0.10^{\mathrm{a}}$ & $-0.41^{\mathrm{a}}$ & 0.42 & 0.31 & 0.99 & 0.54 \\
\hline
\end{tabular}

${ }^{1}$ These values are representative of the change in response compared to the orchard grass hay control. ${ }^{\text {abc }}$ Means within a row, and within a category, with different superscript letters differ $(P<0.05)$. aNDF, Neutral Detergent Fiber assayed with a heat stable amylase and expressed inclusive of residual ash; CO, Chestnut Oak; Coarse, $300-1000 \mu \mathrm{m}$; CP, crude protein; DM, dry matter; Fine, 140 - $178 \mu \mathrm{m}$; SEM, standard error of the mean; YP, Yellow Poplar; WP, White Pine.

basal diet. Digestibility of forage was likely not impacted by CP content of biochar. Inherent differences among tree types may play a role in the chemical composition, structure, and porosity of the pyrolized biochar product (Figure 1). In addition, there may be mineral deposits in the different tree types used for biomass in our study that could be attributed to nutrient cycling of trees during growth or harvest [14]. Biochar is composed of a variety of biomass feedstocks and possesses variable properties due to differences in production and postproduction practices [15] [16]. Therefore, biochar characteristics can vary depending on biomass source, region, and pyrolysis procedure which could lead to unavoidable differences in rumen fermentation.

Total gas production increased with the addition of biochar to the basal diet of orchard grass hay. Gas production has been utilized for feed evaluation to assess the kinetics of fiber digestion in vitro [17] [18]. Thus, an increase in gas production with the finer particle-sized biochar may indicate an increase in rumen fermentation kinetics. Biochar has been utilized as a feed additive in an attempt to establish a new microbial habitat and may alter biofilm activity in the rumen [19]. In addition, biochar may improve microbial-growth efficiency [6] [8]. However, very little is known how biochar impacts cell wall degradation mechanistically [20]. Previous studies have shown no differences in gas production when biochar is utilized during in vitro rumen fermentation [11] [20]. However, 

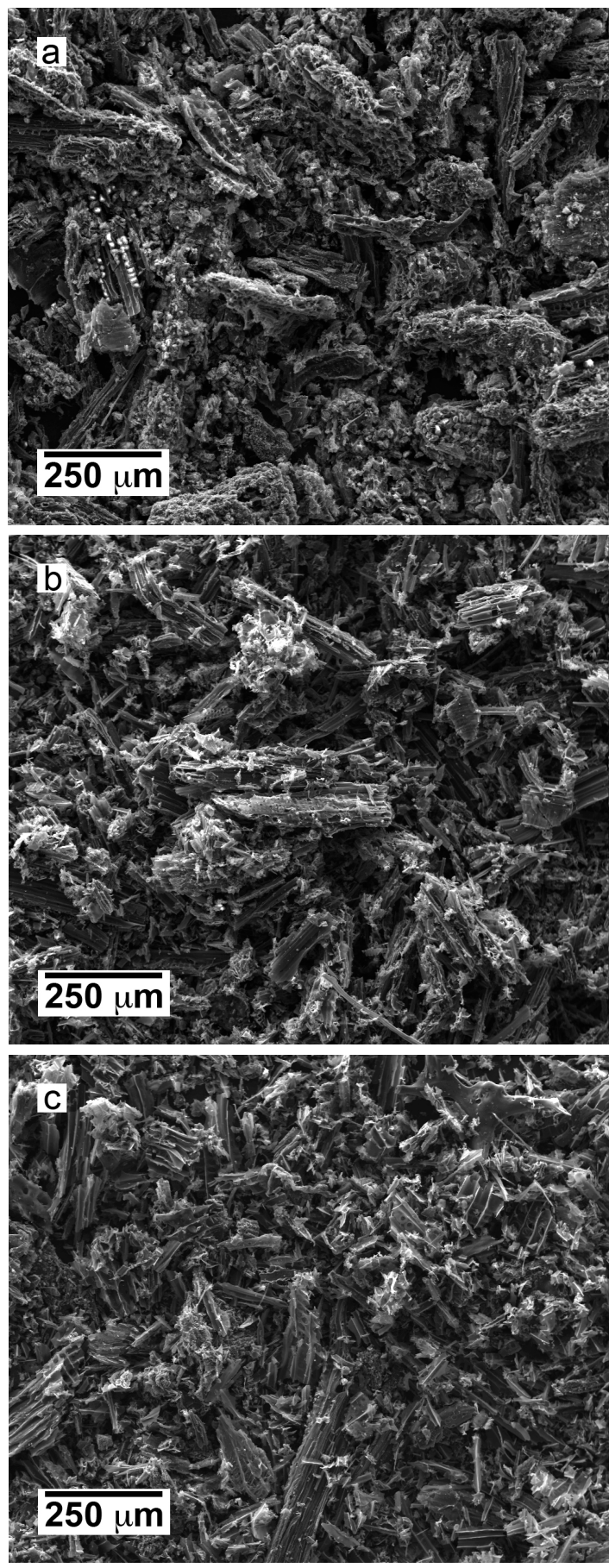

Figure 1. Representative SEM images acquired from Fine $(<178 \mu \mathrm{m})$ particle size samples of biochars sourced from chestnut oak (a), yellow poplar (b), and white pine (c). Images were acquired at $100 \times$.

biochar utilized in the mentioned studies were composed of various starting materials and biochar particle sizes. Therefore, different sources of biochar may respond differently to rumen fermentation due to structural and compositional differences of the starting material. Additionally, the basal diet utilized in [20] (130 g/kg of CP and $465 \mathrm{~g} / \mathrm{kg}$ of NDF, DM basis) [11] (104.2 g/kg of CP and 613 
$\mathrm{g} / \mathrm{kg}$ of aNDF, DM basis) are of greater forage quality than the orchard grass hay $(98.31 \mathrm{~g} / \mathrm{kg}$ of CP and $704.02 \mathrm{~g} / \mathrm{kg}$ of aNDF, DM basis) used in the current study. Thus, biochar may improve rumen fermentation of more moderate-quality forages compared with higher-quality forages.

Biochar decreased in vitro true digestibility of orchard grass hay in this study. Biochar source did not influence these differences. However, Fine particle-sized biochar was more digestible. In addition, the digestibility of $\mathrm{CP}$ suffered due to Fine particle-sized biochar composed of WP and CO. Thus, biochar source and particle size may differentiate the overall structure and porosity of biochar material potentially impacting microbial forage interaction. Starting material and temperature of pyrolysis can contribute to sorptive potential of biochar [1]. Studies determining the influence of biochar on forage digestibility are limited. However, biochar did not affect DM degradability of a hay and mixed ration substrate [20]. This study utilized biochar from three different sources: gasified biochar, straw-based biochar, and a wood-based biochar as the additives to the diet [20]. Contrarily, biochar produced from rice husks that were subjected to pyrolysis $\left(\sim 900^{\circ} \mathrm{C}\right)$ increased the solubilized DM percentage [5]. Ultimately, biochar starting material and particle size may be an important factor to discern the effectiveness of biochar as a feed additive due to changes in forage digestibility.

Volatile fatty acid (VFA) production was not influenced by biochar composition or particle size in this study. In addition, the acetate: propionate ratio was not influenced by biochar addition. In contrast, biochar mixed with grass silage or hay increased VFA production in vitro [11]. These differences in VFA production may be attributed to the differing levels of biochar utilized $(84 \mathrm{~g} / \mathrm{kg}$ DM or $186 \mathrm{~g} / \mathrm{kg} \mathrm{DM})$ and the differences in pyrolysis temperature $\left(350^{\circ} \mathrm{C}\right.$ or $\left.550^{\circ} \mathrm{C}\right)$.

\section{Conclusion}

Ultimately, biochar may reduce digestibility of forage. Differences in biochar tree type and particle size contributed to differences in gas production and DM degradability in this study. Thus, source and particle size of biochar may be an important consideration when assessing the viability of utilizing biochar as a potential feed additive in ruminant diets. Fine particle-sized biochar may be the most efficacious when incorporating in a ruminant diet due to an increase in gas production and an increase in forage digestibility compared to the larger particle size.

\section{Acknowledgements}

The authors wish to thank Proton Power for their support and funding of this project.

\section{References}

[1] Lehmann, J. and Joseph, S. (2009) Biochar for Environmental Management: Science and Technology. Earthscan, London. 
[2] Banner, R.E., Rogosic, J., Burritt, E.A. and Provenza, F.D. (2000) Supplemental Barley and Charcoal Increase Intake of Sagebrush by Lambs. Journal of Range Management, 53, 415-420. https://doi.org/10.2307/4003753

[3] Villalba, J.J., Provenza, F.D. and Banner, R.E. (2002) Influence of Macronutrients and Activated Charcoal on Intake of Sagebrush by Sheep and Goats. Journal of Animal Science, 80, 2099-2109. https://doi.org/10.2527/2002.8082099x

[4] Toth, J.D. and Dou, Z. (2016) Use and Impact of Biochar and Charcoal in Animal Production Systems. In: Guo, M., He, Z. and Uchimiya, M., Eds., Agricultural and Environmental Applications of Biochar: Advances and Barriers, Soil Science Society of America, Inc., Madison, 199-224. https://doi.org/10.2136/sssaspecpub63.2014.0043.5

[5] Leng, R.A., Inthapanya, S. and Preston, T.R. (2012) Biochar Lowers Net Methane Production from Rumen Fluid In Vitro. Livestock Research Rural Development, 24, 103.

[6] Leng, R., Inthapanya, S. and Preston, T.R. (2012) Methane Production Is Reduced in an In Vitro Incubation When the Rumen Fluid Is Taken from Cattle that Previously Received Biochar in their Diet. Livestock Research Rural Development, 24, 211.

[7] Leng, R., Inthapanya, S. and Preston, T.R. (2013) All Biochars Are Not Equal in Lowering Methane Production in in Vitro Rumen Incubations. Livestock Research Rural Development, 25, 106.

[8] Leng, R.A., Preston, T.R. and Inthapanya, S. (2012) Biochar Reduces Enteric Methane and Improves Growth and Feed Conversion in Local "Yellow" Cattle Fed Cassava Root Chips and Fresh Cassava Foliage. Livestock Research Rural Development, 24, 199.

[9] AOAC (1990) Official Method of Analysis. 15th Edition, Association of Official Analytical Chemists, Washington DC.

[10] Pereira, C., Muetzel, R., Camps, S., Arbestain, M., Bishop, P., Hina, K. and Hedley, M. (2014) Assessment of the Influence of Biochar on Rumen and Silage Fermentation: A Laboratory-Scale Experiment. Animal Feed Science and Technology, 196, 220-231.

[11] McDougall, E. (1948) Studies on Ruminant Saliva. The Composition and Output of Sheep's Saliva. Biochemical Journal, 43, 99-109. https://doi.org/10.1042/bj0430099

[12] Erwin, E., Marco, G. and Emery, E. (1961) Volatile Fatty Acid Analyses of Blood and Rumen Fluid by Gas Chromatography. Journal of Dairy Science, 44, 1768-1771. https://doi.org/10.3168/jds.S0022-0302(61)89956-6

[13] Marten, G. and Barnes, R. (1980) Prediction of Energy Digestibility of Forages with In Vitro Rumen Fermentation and Fungal Enzyme Systems. In: Pigden, W.J., Balch, C.C. and Graham, M., Eds., Workshop on Standardization of Analytical Methodology for Feed, International Development Research Centre, Ottawa.

[14] Heilman, P. and Norby, R.J. (1998) Nutrient Cycling and Fertility Management in Temperate Short Rotation Foresty Systems. Biomass Bioenergeering, 14, 361-370. https://doi.org/10.1016/S0961-9534(97)10072-1

[15] Manya, J.J. (2012) Pyrolysis for Biochar Purposes: A Review to Establish Current Knowledge Gaps and Research Needs. Environmental Science and Technology, 46, 7939-7954. https://doi.org/10.1021/es301029g

[16] Spokas, K.A., Cantrell, K.B., Novak, J.M., Archer, D.A., Ippolito, J.A., Collins, H.P., Boateng, A.A., Lima, I.M., Lamb, M.C. and McAloon, A.J. (2012) Biochar: A Synthesis of Its Agronomic Impact beyond Carbon Sequestration. Journal of Environ- 
mental Quality, 41, 973-989. https://doi.org/10.2134/jeq2011.0069

[17] Menke, K.H., Raab, L., Salewski, A., Steingass, H., Fritz, D. and Schneider, W. (1979) The Estimation of the Digestibility and Metabolisable Energy Content of Ruminant Feeding Stuffs from the Gas Production When They Are Incubated with Rumen Liquor. Journal of Agricultural Science, 93, 217-222. https://doi.org/10.1017/S0021859600086305

[18] Menke, K.H. and Steingass, H. (1988) Estimation of the Energetic Feed Value Obtained from Chemical Analysis and in Vitro Gas Production Using Rumen Fluid. Animal Research and Development, 28, 7-55.

[19] Leng, R.A. (2014) Interactions between Microbial Consortia in Biofilms: A Paradigm Shift in Rumen Microbial Ecology and Enteric Methane Mitigation. Animal Production Science, 54, 519-543.

https://doi.org/10.1071/AN13381

[20] Hansen, H.H., Storm, I.M.L.D. and Sell, A.M. (2012) Effect of Biochar on In Vitro Rumen Methane Production. Acta Agriculturae Scandinavica Section A: Animal Science, 62, 305-309. https://doi.org/10.1080/09064702.2013.789548

Submit or recommend next manuscript to SCIRP and we will provide best service for you:

Accepting pre-submission inquiries through Email, Facebook, LinkedIn, Twitter, etc. A wide selection of journals (inclusive of 9 subjects, more than 200 journals)

Providing 24-hour high-quality service

User-friendly online submission system

Fair and swift peer-review system

Efficient typesetting and proofreading procedure

Display of the result of downloads and visits, as well as the number of cited articles Maximum dissemination of your research work

Submit your manuscript at: http://papersubmission.scirp.org/

Or contact as@scirp.org 